\title{
Effect of estradiol on proliferation and differentiation of side population stem/progenitor cells from murine endometrium
}

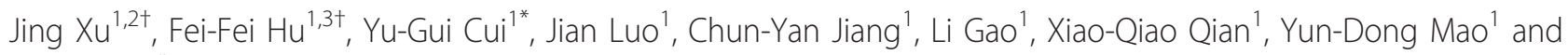
Jia-Yin Liu ${ }^{1 *}$

\begin{abstract}
Background: In our previous study, endometrium side population cells (SP cells) were isolated from postpartum murine uterus, and characterized by a heterogeneous population of stem/progenitor cells. In this study, we investigated the effect of estrogen on the proliferation and differentiation of SP cells.

Methods: SP and non-SP cells of postpartum murine endometrium were isolated by DNA dye Hoechst 33342. The expression of estrogen receptor 1 (ESR1) was measured by reverse transcription polymerase chain reaction (RT-PCR), Real-time PCR, Western blot, immunofluorescence and immunohistochemistry. The proliferation and differentiation of SP cells treated with different concentrations [10(-8) M-10(-6) M] of estradiol (E2) and E2+ ICl182780 (Faslodex, inhibitor of ESR1) were measured by 3-(4, 5-dimethylthiazoly1-2)-2,5-diphenyltetrazolium bromide(MTT) and clonogenic assays.
\end{abstract}

Results: (1) SP cells expressed ESR1 at a higher level than non-SP cells. (2) The level of E2 in the serum and the expression of ESR1 in the uterus of postpartum murine changed in the same manner with the ratio of SP cells to total uterus cells at a different postpartum time point. ESR1, as ABCG2 is also predominantly located in the stroma and the glandular epithelium of the uterus. (3) 10(-6) M E2 notably promoted the proliferation of SP cells after treatment for $24 \mathrm{~h}$. This effect could be inhibited by ICI182780. E2 at the concentration of 10(-7) M or 10(-8) M was sent to impair the large cloning efficiency (CE) of SP cells.

Conclusions: The effect of estrogen on the proliferation and differentiation of endometrium SP cells via ESR1 was observed and it was in a concentration dependent fashion. Clearly, more work is needed to understand the in vivo effect of E2 at the physiological concentration on the differentiation of SP cells.

\section{Background}

It has been proposed that human endometrium contain a population of stem cells which are responsible for their remarkable regenerative ability $[1,2]$. Side population cells (SP cells) have been shown in many adult tissues, and the phenotypes of SP cells might represent common molecular features for a wide variety of stem cells [1-3]. In a previous study, SP cells were isolated from the endometrium of postpartum murine uterus and these SP cells

\footnotetext{
*Correspondence: cuiygnj@njmu.edu.cn; jyliu_nj@126.com

+ Contributed equally

'State Key Laboratory of Reproductive Medicine, Center of Clinical Reproductive Medicine, First Affiliated Hospital, Nanjing Medical University, Nanjing 210029, China

Full list of author information is available at the end of the article
}

were characterized by a heterogeneous population of stem/progenitor cells [3]. Estrogen is an important hormone for repairing postpartum uterus endometrium repairing. Estrogen receptor (ESR) has two isoforms: ESR1 and ESR2. Although both ESR1 and ESR2 are present in the endometrium, ESR1 seems to be the primary mediator of the estrogenic action in these tissues [4]. Some investigators found that ESR1 amplification and over-expression is likely to have a growth stimulatory effect on endometrium-derived cancer cells [5]. It is important to know how SP cells participate in the repair of cyclical and postpartum endometrium, and the effect of estrogen (via ESR1) in this procedure. Meanwhile, research on the proliferation and differentiation of

\section{Biomed Central}


endometrium SP cells, as well as the effect of steroid hormones, will add knowledge to our understanding of pathophysiology of endometriosis.

The objectives of the present study were: 1) To evaluate the potential of the in vivo effect of estrogen on the proliferation and differentiation of SP cells during endometrium repairing by investigation of the serum estradiol level and the expression of ESR1 in murine uterus at different postpartum stages. 2) To observe directly the in vitro effect of estradiol on the proliferation and differentiation of cultured SP cells treated with different concentrations of $E_{2}$ and ICI182780 (inhibitor of ESR1).

\section{Methods}

\section{Animals}

Female ICR mice [Institute of Cancer Research (ICR)], aged 6-8 weeks, were used. ICR mice were purchased from Model Animal Research Center of Nanjing University (Nanjing, China). Sixty mice were divided into six groups based on their postpartum day (Day 1, 7, 14, 18, 21, 28) to detect serum estradiol $\left(\mathrm{E}_{2}\right)$ level and the expression of estrogen receptor 1 (ESR1) in postpartum endometrium. Another 60 ICR mice were used at postpartum Day 18 to isolate endometrium side population (SP) cells. Animal studies were conducted according to the protocols approved by the Animal Care and Use Committee of Nanjing Medical University.

\section{Cell preparation}

Endometrium SP cells were isolated and cultured using pancreatic enzyme, collagenase, as well as mechanical separation [3]. Cells were suspended at a concentration of $1 \times 10^{6}$ cells $/ \mathrm{ml}$ and were then incubated in $5 \mu \mathrm{g} / \mathrm{ml}$ Hoechst 33342 dye (Sigma-Aldrich, St. Louis, MO). Suspensions were analyzed and sorted using a FACS Vantage SE cell sorter (Becton Dickinson, Franklin Lakes, NJ) with a $350 \mathrm{~nm}$ UV diode laser. Hoechst 33342 fluorescence was measured at both $402-446 \mathrm{~nm}$ for Hoechst blue and $640 \mathrm{~nm}$ for Hoechst red.

\section{Immunocytochemistry}

The freshly sorted SP cells were collected and re-suspended to a final concentration of $1 \times 10^{6} / \mathrm{ml}$. An aliquot of $0.2 \mathrm{ml}$ of the suspension was used for each cell smear. Cells were cytospun onto plus-coated slides, air dried, and fixed in acetone for $10 \mathrm{~min}$ at $4^{\circ} \mathrm{C}$. The sections were incubated with anti- ESR1 pAb (1:50 dilution, Santa Cruz, CA) for 24 hours and then with FITC secondary antibodies. Nuclear staining was performed with $5 \mu \mathrm{g} / \mathrm{ml}$ Hoechst 33342. The percentage of positive expression of ESR1 was calculated by counting positive cells in every 400 cells from three independent experiments.

Five-micrometer-thick coronal sections (paraffinembedded) of postpartum mouse uterus were exposed to citrate buffer $(0.01 \mathrm{M}, \mathrm{pH}$ 6.0) and heated in a microwave oven for 10 minutes for antigen retrieve. The sections were treated with $0.3 \%$ hydrogen peroxide in methyl alcohol for 20 minutes and blocked with 10\% normal goat serum (Zhongshan Biotechnology Co. Ltd., Beijing, China) for 2 hours. It was allowed to react for 12 hours with the primary rabbit anti-ESR1 antibody (1:50 dilution, Santa Cruz, CA) or normal rabbit IgG (1:100 dilution, Santa Cruz, CA) as a negative control. Sections were then incubated with horseradish peroxidase (HRP)-conjugated goat anti-rabbit secondary antibody (1:200 dilution, Santa Cruz Biotechnology Inc, CA) at room temperature for 1 hour and the reactivity was visualized with peroxidase-substrate solution (diaminobenzidine, DAB) until the desired stain intensity developed. Sections were counterstained with Harris's hematoxylin for 35 seconds.

\section{RT-PCR and real-time PCR}

Total RNA was extracted from the pellets of sorted SP and main population (MP, non-SP) cells using a Trizol Reagent (Invitrogen Corporation, Carlsbad, CA) and was reverse-transcribed into cDNA with a reverse transcription kit (Takara Bio Inc., Shiga, Japan) as per manufacturer instruction. The total RNA and cDNA of postpartum mouse uterus were prepared as the same way. $\beta$-actin was used as a housekeeping gene. PCR was performed using the following primers: $\beta$-actin primers, 5'-CCG TAA AGA CCT CTA TGC C-3' and 5'-CTC AGT AAC AGT CCG CCT A-3' for a 278-bp fragment; ESR1 primers, 5'-GCA CAG GAT GCT AGC CTT GTC TC-3' and 5'-CCA GCT TGC AGG TTC ATT GTG-3' for a 98-bp fragment. Cycling conditions for both $\beta$-actin and ESR 1 were $94^{\circ} \mathrm{C}$ for 5 minutes, $94^{\circ} \mathrm{C}$ for 30 seconds, $56^{\circ} \mathrm{C}$ for 1 minute, and $72^{\circ} \mathrm{C}$ for 1 minute, 35 cycles. The PCR products were separated on $2 \%$ agarose gels for analysis.

Real-time PCR primers were the same for RT-PCR. Cycling conditions for $\beta$-Actin and ESR 1 were $95^{\circ} \mathrm{C}$ for 10 seconds, $95^{\circ} \mathrm{C}$ for 5 seconds, $60^{\circ} \mathrm{C}$ for 31 seconds, 40 cycles. Melting curve analysis was performed to confirm the real-time qPCR products. Relative abundances of the target mRNAs were calculated using the $2{ }_{-}{ }^{\Delta \Delta C T}$ method [6].

\section{Western blot}

The different postpartum days (Day1, 7, 14, 18, 21, 28) of mouse uteri were homogenated on ice with lysis buffer $(7$ $\mathrm{mol} / \mathrm{L}$ urea, $2 \mathrm{~mol} / \mathrm{L}$ thiourea, $4 \%$ [w/v] 3-[(3-cholamidopropyl)-dimethylammonio]-1-propane sulfonate (CHAPS), $2 \%[\mathrm{w} / \mathrm{v}]$ dithiothreitol (DTT), 2\% [v/v] immobilized $\mathrm{pH}$ gradient [IPG] buffer, $\mathrm{pH} 3-10)$ in the presence of $1 \%(\mathrm{v} / \mathrm{v})$ protease inhibitors cocktail kit (Pierce Biotechnology, Rockford, Illinois, USA). After centrifugation at $40000 \mathrm{~g}$ at $4^{\circ} \mathrm{C}$ for 1 hour, protein extracts in the supernatants were 
collected and stored at $-80^{\circ} \mathrm{C}$ until use. Aliquots of $50 \mu \mathrm{g}$ protein extracts from each sample were loaded and separated by $12 \%$ sodium dodecyl sulfate polyacrylamide gel electrophoresis (SDS-PAGE) and the resulting proteins were then transferred onto a nitrocellulose membrane. After treatment with blocking solution (5\% non-fat milk powder in Tris-buffered saline [TBS; $\mathrm{pH} 7.4$ ]) for 2 hours, the membranes were incubated with rabbit polyclonal antibodies of ESR1 (1:50, Santa Cruz Biotechnology, Santa Cruz, CA), or $\beta$-tubulin (1:5000, Abcam, Cambridge Science Park, Cambridge, UK) at $4^{\circ} \mathrm{C}$ overnight. The membrane was then incubated with HRP-conjugated antirabbit secondary antibodies (1:1000, Zhongshan Biotechnology Co. Ltd., Beijing, China) for 1 hour at $37^{\circ} \mathrm{C}$, and examined by enhanced chemiluminescence (Amersham Biosciences, Uppsala, Sweden). The membranes were then scanned, and the signal intensity of each band was quantified using AlphaEaseFC (Fluorchem 5500) software (Alpha Innotech Corp., CA). Relative protein levels in each sample were normalized to the $\beta$-tubulin level in order to standardize the loading variations.

\section{Serum preparation and Hormone assays}

Mice of different postpartum time (day1, 7, 14, 18, 21, 28) were anesthetized by $1 \%$ pentobarbital sodium and approximately $1 \mathrm{ml}$ blood was withdrawn from the right ventricle. The blood samples were kept at room temperature for 2 hours, centrifuged at $1500 \mathrm{~g}$ for 10 minutes, and the sera were stored at $-80^{\circ} \mathrm{C}$ until use. Concentrations of estradiol in the sera and conditioned medium of cultured SP cells were measured via a sensitive $(<0.02 \mathrm{ng} / \mathrm{mL})$ and reproducible (total coefficient of variation $[\mathrm{CV}],<10 \%$ ) radioimmunoassay (RIA) with a measurement range from 0.1 to $20 \mathrm{ng} / \mathrm{mL}$. The RIA kits were obtained from the Beifang Biotechnique Institute (Beijing, China).

\section{Clonogenic assay}

SP cells were seeded in triplicate at 500 cells $/ \mathrm{cm}^{2}$ in flatbottomed, 6-well culture plates. For the first 2 days, the culture medium was phenol red-free DMEM/F-12 (Gibco, USA) containing $5 \% \mathrm{FBS}, 100 \mathrm{IU} / \mathrm{ml}$ penicillin, and $10 \mathrm{mg} / \mathrm{ml}$ streptomycin. Starting from Day 3, the cells were treated with different concentrations $\left(10^{-8}-10^{-6} \mathrm{M}\right)$ of $17 \beta \mathrm{E}_{2}$ or $17 \beta \mathrm{E}_{2}$ in the presence of ICI182780 (inhibiter of ESR1, $\left.10^{-6} \mathrm{M}\right)$, Cells were cultured for 15 days in $5 \%$ $\mathrm{CO}_{2}: 95 \%$ air. The culture medium was changed every 2 days. Colonies were monitored microscopically daily to ensure that they were derived from single cells.

The dishes for clone analysis were fixed in $4 \%$ paraformaldehyde in PBS for 30 minutes, stained with Harris's hematoxylin for 5 minutes, then washed in running tap water for 20 minutes and dried. Clusters of cells were considered colonies when they were visible macroscopically and contained more than 50 cells. Colonies more than 70 cells were considered large clones. Colonies were counted and images were recorded. The cloning efficiency $(\mathrm{CE})$ was determined from the formula: CE $(\%)=$ (number of colonies/number of cells seeded) $\times 100 \%$.

\section{Cell proliferation and viability assays}

The reduction of tetrazolium salts is now widely accepted as a reliable way to examine cell proliferation. The 3-(4,5dimethylthiazoly1-2)-2,5-diphenyltetrazolium bromide (MTT) is reduced by metabolically active cells, in part by the action of dehydrogenase enzymes, to generate reducing equivalents such as NADH and NADPH. The resulting intracellular purple formazan can be solubilized and quantified by spectrophotometric means. Briefly, SP cells were plated at a density of $3 \times 10^{4}$ cells/well in 96-well plates, cultured for 2 days in phenol red-free serum medium and then exposed with different concentrations $\left(10^{-8}-10^{-6} \mathrm{M}\right)$ of $17 \beta \mathrm{E}_{2}$ in the presence or absence of ICI182780 $\left(10^{-6} \mathrm{M}\right)$ for 24 hours. The cells were then incubated with $0.5 \mathrm{mg} / \mathrm{ml} \mathrm{MTT}$ for 4 hours at $37^{\circ} \mathrm{C}$. The media was carefully removed and $150 \mu \mathrm{l}$ of DMSO were added to each well for 15 minutes in order to solubilize the dark blue formazan crystals formed in intact cells. The absorbance was measured at $570 \mathrm{~nm}$ with the microplate reader (Bio-Tek ELX800, USA).

\section{Statistics}

Each experiment was repeated at least three times. All data were presented as mean $\pm \mathrm{SD}$. One-way analysis of variance was used to compare the mRNA and protein levels. Chi-square analysis was used to compare the rates of SP cell large clones. A value of $\mathrm{P}<0.05$ was considered statistically significant.

\section{Results \\ Variation of SP cells proportions along with postpartum days}

Fluorescence activated cell sorter (FACS) analysis showed that along with the changing of postpartum time (Day1, 3, 7, 14, 18, 21, 28, 60) the proportion of SP cells increased significantly and then gradually decreased after Day $18(\mathrm{P}<0.05)$ (Figure $1 \mathrm{~A})$.

\section{Variation trend of serum $E_{2}$ level along with postpartum days}

Serum estradiol level was high at D1, and then remarkably decreased at Day 7 (Figure $1 \mathrm{~B}$ ). The $\mathrm{E}_{2}$ level, on the other hand, had a gradual increase from Day 7 to Day 18 after which it showed a decreasing trend $(\mathrm{P}<$ 0.05 ) (Figure 1B). This trend is representative of the change in SP cell proportion. These findings suggest that estradiol may play a role in the regulation of SP cells, which participate in the regeneration of postpartum mice endometrium. 


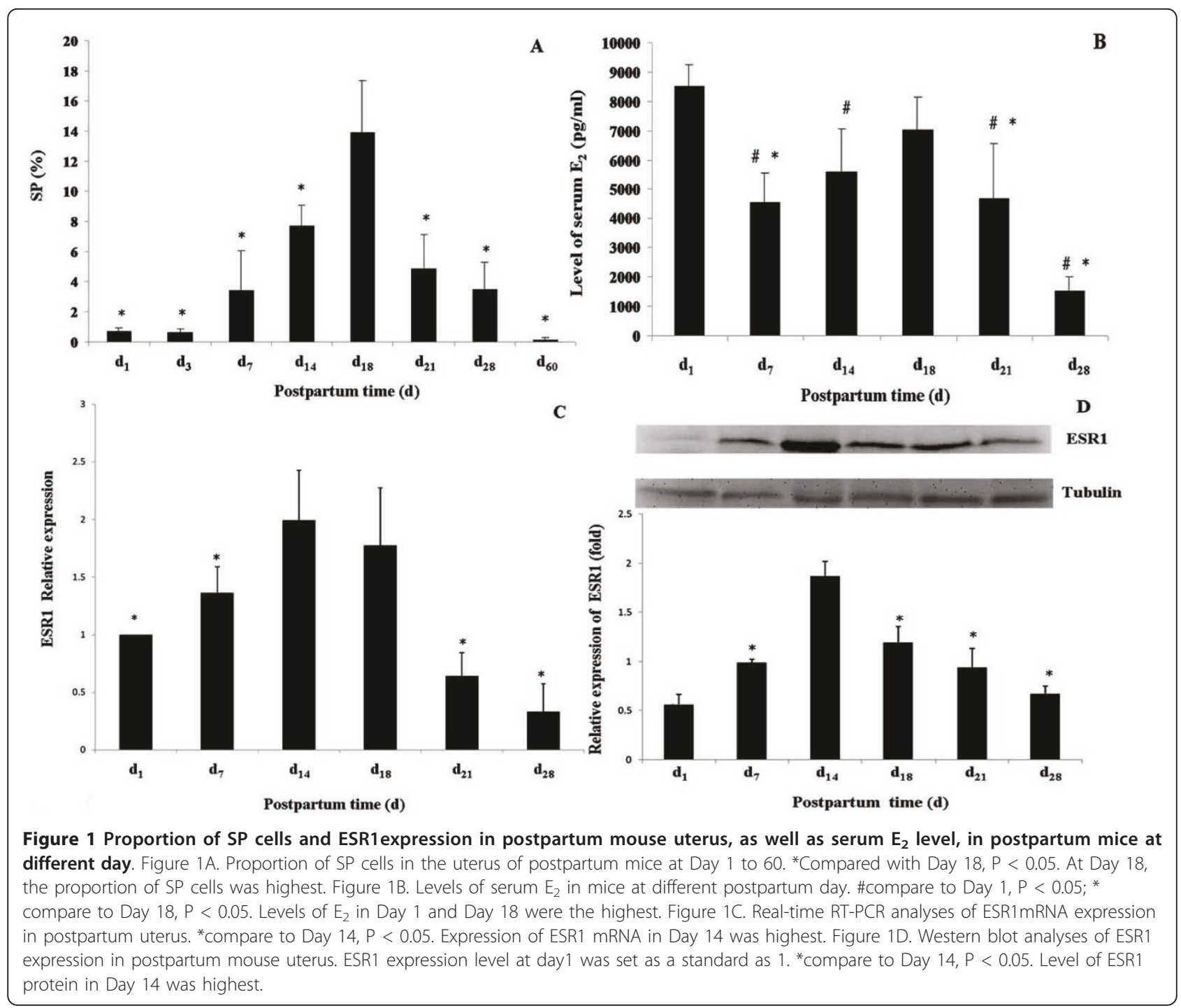

\section{Expression of ESR1 in mouse endometrium at different postpartum days}

Analysis with real-time PCR showed increased ESR1 expression within the first 14 days of postpartum, with the highest peak at Day $14(\mathrm{P}<0.05)$ (Figure 1C). This trend was similar to the trend of SP cell ratio in the endometrium of postpartum mice. Western blot showed the same result as PCR analysis. Compared with other days of postpartum, ESR1 obviously expressed at highest level at Day 14 $(\mathrm{P}<0.05)$ (Figure 1D).

Immunohistochemistry showed the same variation as Real-time PCR analyses. Luminal epithelium at Day 1 expressed low level of ESR1, whereas stroma and glandular epithelium at Day 7 showed mid level of ESR1 expression. Stroma at Day 14 expressed high level of ESR1. From Day 18 to Day 28, expression of ESR1 decreased gradually. At Day 18, significant amounts of ESR1 were expressed in the Glandular epithelium. ESR1 expression was seen to decrease significantly at Day 21 and Day 28 (Figure 2).

\section{Preferential expression of ESR1 in SP cells when} compared with non-SP cells

We also examined the basal expression of ESR1 in SP cells and non-SP cells. RT-PCR analyses showed that the expression of ESR1 mRNA was higher in SP cells than that in non-SP cells $(P<0.05)$ (Figure 3B, C). Immunocytochemical analysis showed that $75.18 \pm$ $5.47 \%$ of SP cells expressed ESR1, and only $32.28 \pm 4.3 \%$ of non-SP cells expressed ESR1 (Figure 3A). These findings suggested that a large number of SP cells were able to respond to estrogen (target cells of estrogen).

\section{Cell proliferation of SP cells modulated by $17 \beta \mathrm{E}_{2}$}

To study the proliferative effects of $17 \beta \mathrm{E}_{2}$, SP cells were treated with different concentrations $\left(10^{-8}-10^{-6} \mathrm{M}\right)$ of 


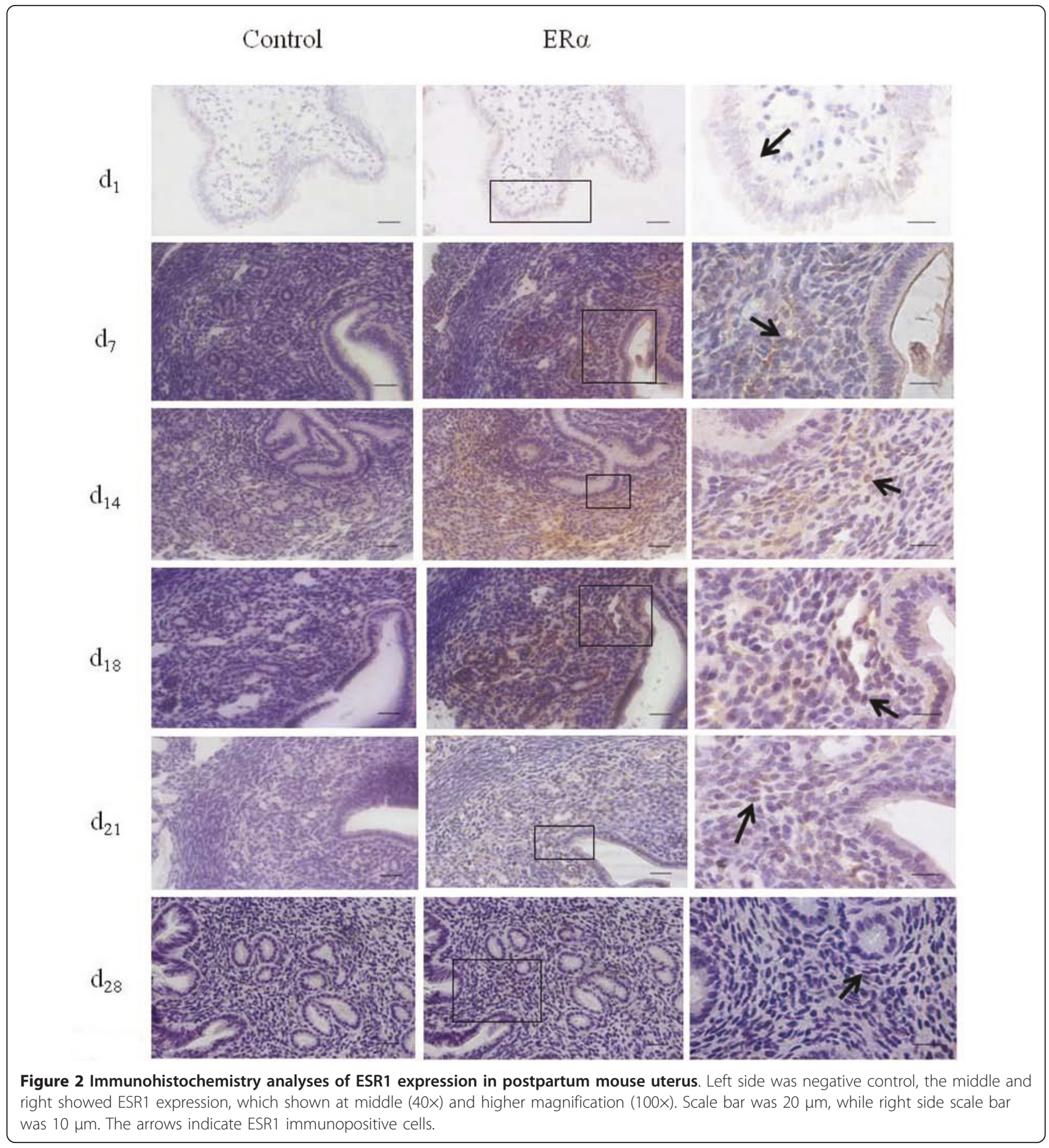

$17 \beta \mathrm{E}_{2}$ in the presence or absence of ICI182780 $\left(10^{-6} \mathrm{M}\right)$. $17 \beta \mathrm{E}_{2}$ at the dose of $10^{-6} \mathrm{M}$ induced a significant increase in SP cell numbers $(P<0.05)$, even though $\mathrm{E}_{2}$ at lower doses $\left(10^{-7}, 10^{-8} \mathrm{M}\right)$ could not significantly change SP cell numbers $(\mathrm{P}>0.05)$ (Figure $4 \mathrm{~A})$. The stimulated proliferation was blocked by ICI182780 (P < $0.05)$ indicating the effect was specifically mediated through estrogen receptors.
Variation of large CE of SP cells after $17 \beta \mathrm{E}_{2}$ treatment

Total CE of SP cells in all of $17 \beta E_{2}$ treated groups did not significantly change. The CEs of large colonies were

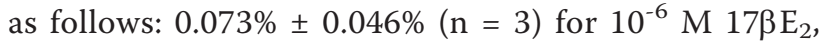
$0.04 \% \pm 0.031 \%(\mathrm{n}=3)$ for $10^{-7} \mathrm{M} 17 \beta \mathrm{E}_{2}, 0.027 \% \pm$ $0.011 \%(\mathrm{n}=3)$ for $10^{-8} \mathrm{M} 17 \beta \mathrm{E}_{2,}, 0.126 \% \pm 0.042(\mathrm{n}=3)$ for $10^{-6} \mathrm{M} 17 \beta \mathrm{E}_{2}+\mathrm{ICI} 182780,0.073 \% \pm 0.023 \%(\mathrm{~N}=3)$

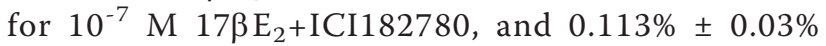




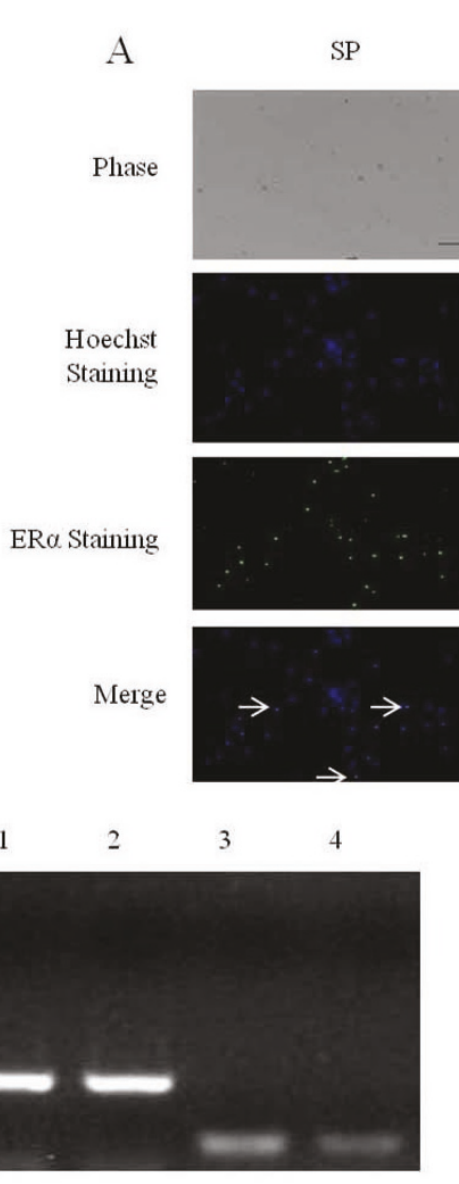

10

B

B

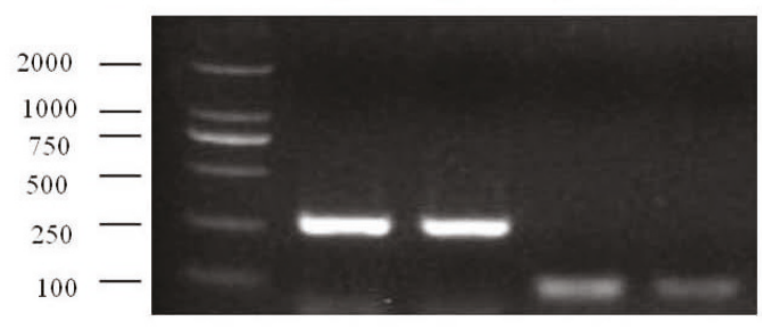

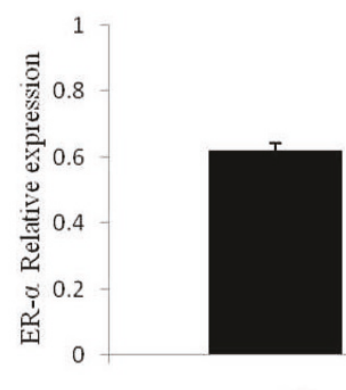

non-SP
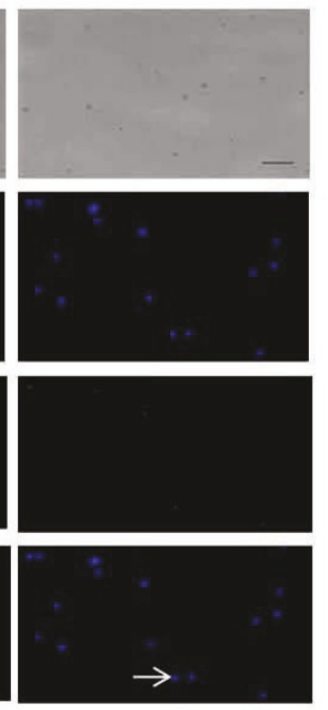

non-SP

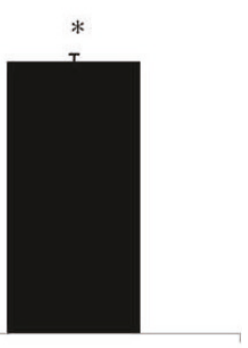

SP

Figure 3 Expression of ESR1 in SP and non-SP cells. Figure 3A. Immunocytochemical analyses of ESR1 expression in SP and non-SP cells. Nuclear Hoechst staining (blue) and immunofluorescent labeling of ESR1 (green) were merged. Scale bar, $100 \mu$ m. The arrows indicate ESR1 immunopositive cells (Hoechst and ESR1 staining merged). Figure 3B, C. RT-PCR analyses of ESR1 expression in SP and non-SP cells. 1. SP Actin; 2. Non-SP Actin; 3. SP ESR1; 4. Non-SP ESR1. *P $<0.05$.

$\left(\mathrm{n}=3\right.$ ) for $10^{-8} \mathrm{M} 17 \beta \mathrm{E}_{2}+\mathrm{ICI} 182780$. There was a significant decrease in CE of large colonies of SP cells in groups treated with $10^{-7} \mathrm{M}$ and $10^{-8} \mathrm{M}$ of $17 \beta \mathrm{E}_{2}$. ICI182780 was seen to block this effect $(P<0.05)$ (Figure 4C). The size distribution of these SP cells colonies was also examined by scoring 344 colonies from nine samples and sorting them into numerical order. Figure $4 \mathrm{~B}$ shows that colonies could be categorized into two groups: small colonies ( $<70$ cells) or large colonies (>70 cells).

\section{Discussion}

Adult stem cells have tissue-specific function as they are known to repair and maintain their corresponding tissues [3]. The concept that endometrial regeneration is mediated by endometrial stem/progenitor cells was proposed many years ago $[7,8]$. It is widely believed that endometrial restoration after menses suggests a need for estrogen-primed proliferation. In the previous study, it was shown that SP cells of postpartum murine endometrium were a heterogeneous population of endometrial stem/progenitor cells [3]. In the mouse, the normal estrus cycle recovers several days after the lactation is over, which is approximately 21-24 days after parturition. In this study, an initial increase was seen in the percentage of SP cells in postpartum murine endometrium. This increase was observed until Day 18, after which a gradual decrease was recorded. It was suggested that this phenotype might correlate with endocrinological hormonal changes after parturition. Uterus is an important target organ of estrogen. Estrogen receptor (ER) has two isoforms: ESR1 and ESR2. ESR1 is the main isoform of ER in humans and rodents. Although ESR1 and ESR2 were both expressed in endometrium, when compared with the wild type, it was seen that the uterus of the ESR1 knockout mice is immature with 


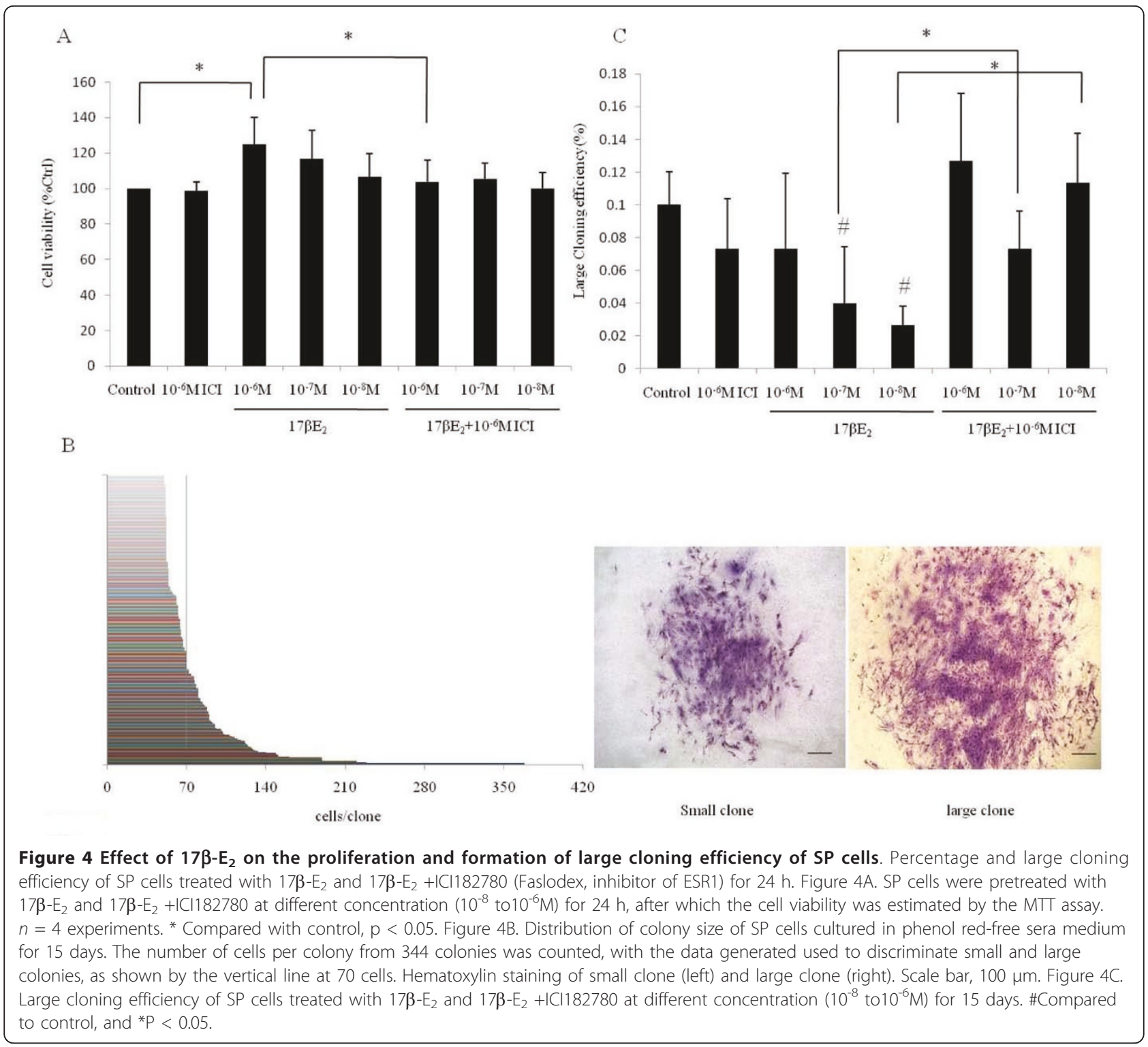

fewer glands. Even with the administration of exogenous $E_{2}$, there was no thickening of the endometrium or the muscular layer in ESR1 knockout mice. This is indicative of the primary function of ESR1 in the uterus $[9,10]$. Estrogen regulates endometrial cell survival, viability and mitogenic activity via ESR1 [11,12]. Decreased expression of ESR2 has previously been seen in many estrogen-dependent tumors [13]. ESR2 acts as a modulator of ESR1 and has an anti-proliferative and pro-apoptotic role [14]. In this study, it was found that the expression of ESR1 was greater in SP cells, when compared with the expression in non-SP cells. Since ESR1 is the dominant isoform in the uterus, it was assumed that estrogen might regulate SP cells via the ESR1 function of regenerating the endometrium.
The $\mathrm{E}_{2}$ level in serum and the ESR1 expression in uterus showed the same trend with the proportion of SP cells and total uterus cells varying in different postpartum days (Day1 to Day 28). It was found that the $E_{2}$ level in serum gradually increased from postpartum Day 7, and then declined after Day18. However, the ESR1 expression at both the gene level and the protein level peaked at postpartum Day 14. It was reported by Kang et al. [15] that after treatment with 17-ethinyl estradion (EE) (doses of 3.0 and $10.0 \mu \mathrm{g} / \mathrm{kg} /$ day), ESR1 expression decreased in the uterine luminal and glandular epithelium, as well as in the stroma and the uterine smooth muscle cells. The data suggested that the increased endogenous $E_{2}$ level could negatively regulate ESR1 expression in uterus to some extent, which could have 
resulted in the discord of time-course of $E_{2}$ level and ESR1 expression peaks.

In this study, it was found that ESR1 in mouse uterus at postpartum Day 14 was predominantly expressed in endometrium stroma, while it was highly expressed in glandular epithelium at postpartum Day 18. In previous studies, it was found that the ATP-binding cassette superfamily $\mathrm{G}$ member $2\left(\mathrm{ABCG}_{2}\right)$ was mainly expressed in postpartum mouse endometrium stroma. $\mathrm{ABCG}_{2}$ was also expressed in a small part of vascular endothelial cells and glandular epithelium [3]. $\mathrm{ABCG}_{2}$ is specially expressed in SP cells. Estrogen promotes endometrium cell mitosis, which is an important factor for the development and functional maintenance of female reproductive system. In uterus, $E_{2}$ promotes endothelial progenitor cell (EPC) differentiation, migration, proliferation, and apoptosis inhibition [16-18]. The enhanced biological activities in EPC by $E_{2}$ are blocked by the specific ESR1 antagonist ICI182780, which indicates that the effect of estrogen on EPCs is via functional ESR1 in EPCs. In this study, we found that $10^{-6} \mathrm{M} \mathrm{E}_{2}$ could significantly promote proliferation of SP cells in vitro and this effect could be blocked by ICI182780 ( $<$ < 0.05). Three other concentrations of $E_{2}$ at a lower level showed concentration dependent tendency of stimulation of SP cell proliferation although they did not reach statistical significance. Therefore, $E_{2}$ leads to the promotion of SP cells via ESR1 by participating in the regeneration of the endometrium.

Stem cells are able to differentiate, self-renew and replace themselves, into committed progenitors. These committed progenitors are differentiated transit amplifying (TA) cells, which rapidly proliferate and finally differentiate to produce a large number of terminally differentiated functional cells with no capacity for proliferation. It is possible that the large colonies are initiated by putative stem/ progenitor cells and the small colonies are initiated by putative TA cells [2]. In this study, it was found that CE of large clones treated by $10^{-7} \mathrm{M}$ and $10^{-8} \mathrm{M} \mathrm{E}_{2}$ notably decreased and this effect could be blocked by ICI182780 $(\mathrm{P}<0.05)$. With $\mathrm{E}_{2}$ concentration gradually decreasing from $10^{-6} \mathrm{M}$ to $10^{-8} \mathrm{M}$, CE of large clones also showed decreasing trend even though there was not a statistically significant difference recorded $(\mathrm{P}>0.05)$. These results indicated that $E_{2}$ at the circumambient concentration of physiological range could promote the committed differentiation of SP cells in vitro. The physiological serum concentration of $17 \beta \mathrm{E}_{2}$ in postpartum mice is about $10^{-8} \mathrm{M}$. Deasy et al., [17] when studying Duchenne Muscular Dystrophy (DMD), found that the female muscle-derived stem cells (MDSCs) regenerated skeletal muscle more efficiently than those of the males. It was therefore concluded that $E_{2}$ at high concentrations promoted proliferation of SP cells of postpartum mouse endometrial, whereas $E_{2}$ at physiological concentrations could promote differentiation of SP cells.

In clinical practice, many patients become infertile due to declining endometrial regeneration capability. The common reasons include abortion, infection and endocrinal dysfunction. Conversely, abnormal endometrial hyperplasia could lead to endometriosis, functional uterine bleeding and endometrial carcinoma [19-22]. The current study advanced the understanding of the role of SP cells in repairing postpartum endometrium and in the pathological mechanism of abnormal endometrial proliferation, as well as the accumulated materials for experimental and clinical applications of endometrial SP cells.

\section{Conclusions}

In conclusion, evidence provided in the present study indicated that $E_{2}$ promoted SP cells via ESR1, which in turn plays a role in the regeneration of the endometrium. It was observed that $E_{2}$ at high concentrations promoted proliferation of SP cells of postpartum mouse endometrial, while $E_{2}$ at physiological concentrations could lead to the promotion of differentiation of SP cells. Further studies will be required to elucidate the role of SP cells in repairing postpartum endometrium and in the pathological mechanism of abnormal endometrial proliferation.

\section{Acknowledgements}

We thank Ling Wang and Fan Hu for their assistance with the flow cytometry, and Professors Zuomin Zhou \& Jiahao Sha for their technical help. This work was supported by the China National Foundation of Science (81070465, 2006CB944005) and China Jiangsu Health Department Program (XK02200901NG09, H200905). We thank Dr Wang YF, Reproductive Biology Unit and Division of Reproductive Medicine, Ottawa Health Institute, for her help in English language.

\section{Author details}

${ }^{1}$ State Key Laboratory of Reproductive Medicine, Center of Clinical Reproductive Medicine, First Affiliated Hospital, Nanjing Medical University, Nanjing 210029, China. 'Zhenjiang Maternity and Child Health Care Hospital, Zhenjiang, 212000, China. ${ }^{3}$ Department of Gynecology and Obstetrics, Second Affiliated Hospital, Nanjing Medical University, Nanjing 210003, China.

\section{Authors' contributions}

JX and FFH carried out the main experiments and wrote the first draft of manuscript. YGC and JYL, teachers of JX and FFH, designed the study and revised manuscript. YGC investigated data and proofread the final manuscript. JL, CYJ, LG XQQ and YDM participated in some experiments. All authors read and approved the final manuscript.

\section{Competing interests}

The authors declare that they have no competing interests.

Received: 20 January 2011 Accepted: 29 July 2011

Published: 29 July 2011

\section{References}

1. Padykula AH: Regeneration in the primate uterus: the role of stem cells. Ann N Y Acad Sci 1991, 622:47-56.

2. Chan RW, Schwab KE, Gargett CE: Clonogenicity of Human Endometrial Epithelial and Stromal Cells. Biol Reprod 2004, 70:1738-1750. 
3. Hu FF, Xu J, Cui YG, Qian XQ, Mao YD, Liao LM, Liu JY: Isolation and Characterization of Side Population Cells in the Postpartum Murine Endometrium. Reprod Sci 2010, 17:629-642.

4. Hewitt SC, Harrell JC, Korach KS: Lessons in estrogen biology from knockout and transgenic animals. Annu Rev Physiol 2005, 67:285-308.

5. Lebeau A, Grob T, Holst F, Seyedi-Fazlollahi N, Moch H, Terracciano L, Turzynski A, Choschzick M, Sauter G, Simon R: Oestrogen receptor gene (ESR1) amplification is frequent in endometrial carcinoma and its precursor lesions. J Pathol 2008, 216:151-157.

6. Livak KJ, Schmittgen TD: Analysis of relative gene expression data using real-time quantitative PCR and the 2(-Delta Delta C (T)) method. Methods 2001, 25:402-408.

7. Padykula HA, Coles LG, Okulicz WC, Rapaport SI, McCracken JA, King NW Jr, Longcope C, Kaiserman-Abramof IR: The basalis of the primate endometrium: a bifunctional germinal compartment. Biol Reprod 1989, 40:681-690

8. Prianishnikov VA: On the concept of stem cell and a model of functionalmorphological structure of the endometrium. Contraception 1978, 18:213-223.

9. Couse JF, Korach KS: Reproductive phenotypes in the estrogen receptoralpha knochout mouse. Ann Endocrinol 1999, 60:143-148.

10. Lubahn DB, Moyer JS, Golding TS, Couse JF, Korach KS, Smithies O: Alteration of Reproductive function but not prenatal sexual development after insertional disruption of the mouse estrogen receptor gene. Proc Natl Acad Sci USA 1993, 90:11162-11166.

11. Couse JF, Korach KS: Estrogen receptor null mice: what have we learned and where will they lead us? Endocr Rev 1999, 20:358-417.

12. Takahashi K, Nitaom H, Kitao M: Clinical usefulness of determination of estradiol level in the menstrual blood for patients with endometriosis. Nippon Sanka Fujinka Cakkai Zasshi 1989, 41:1849-1850.

13. Bardin A, Boulle N, Lazennec G, Vignon F, Pujol P: Loss of ER beta expression as a common step in estrogen-dependent tumor progression. Endocr Relat Cancer 2004, 11:537-551.

14. Lindberg MK, Moverare S, Skrtic S, Gao H, Dahlman-Wright K, Gustafsson JA, Ohlsson C: Estrogen receptor(ER)-beta reduces ER alpha-regulated gene transcription, supporting a "ying yang" relationship between ER alpha and ER beta in mice. Mol Endocrinol 2003, 17:203-208.

15. Kang JS, Lee BJ, Ahn B, Kim DJ, Nam SY, Yun YW, Nam KT, Choi M, Kim HS, Jang DD, Lee YS, Yang KH: Expression of estrogen receptor alpha and beta in the uterus and vagina of immature rats treated with 17-ethinyl estradiol. J Vet Med Sci 2003, 65:12932-12971.

16. Masuda H, Kalka C, Takahashi T, Yoshida M, Wada M, Kobori M, Itoh R, Iwaguro H, Eguchi M, Iwami Y, Tanaka R, Nakagawa Y, Sugimoto A, Ninomiya S, Hayashi S, Kato S, Asahara T: Estrogen-Mediated Endothelial Progenitor Cell Biology and Kinetics For Physiological Postnatal Vasculogenesis. Circ Res 2007, 101:598-606.

17. Deasy BM, Lu A, Tebbets JC, Feduska JM, Schugar RC, Pollett JB, Sun B, Urish KL, Gharaibeh BM, Cao B, Rubin RT, Huard J: A role for cell sex in stem cell-mediated skeletal muscle regeneration: female cells have higher muscle regeneration efficiency. I Cell Biol 2007, 177:73-86.

18. Giudice LC: Growth factors and growth modulators in human uterine endometrium: their potential relevance to reproductive medicine. Fertil Steril 1994, 61:1-17.

19. Sugawara J, Fukaya T, Murakami T, Yoshida H, Yajima A: Increased secretion of hepatocyte growth factor by eutopic endometrial stromal cells in women with endometriosis. Fertil Steril 1997, 68:468-472.

20. Yoshida S, Harada T, Mitsunari M, Tomio I, Yasuko S, Satoru T, Yumiko I, Sayako H, Naoki T: Hepatocyte growth factor/Met system promotes endometrial and endometriotic stromal cell invasion via autocrine and paracrine pathways. J Clin Endocrinol Metab 2004, 89:823-832.

21. Chegini N, Rossi MJ, Masterson BJ: Platelet-derived growth factor (PDGF), epidermal growth factor (EGF), and EGF and PDGF beta-receptors in human endometrial tissue: localization and in vitro action. Endocrinology 1992, 130:2373-2385

22. Sangha RK, Li XF, Shams M, Ahmed A: Fibroblast growth factor receptor-1 is a critical component for endometrial remodeling: localization and expression of basic fibroblast growth factor and FGF-R1 expression in menorrhagia. Lab Invest 1997, 77:389-402.

doi:10.1186/1477-7827-9-103

Cite this article as: Xu et al:: Effect of estradiol on proliferation and differentiation of side population stem/progenitor cells from murine endometrium. Reproductive Biology and Endocrinology 2011 9:103.

\section{Submit your next manuscript to BioMed Central and take full advantage of:}

- Convenient online submission

- Thorough peer review

- No space constraints or color figure charges

- Immediate publication on acceptance

- Inclusion in PubMed, CAS, Scopus and Google Scholar

- Research which is freely available for redistribution

Submit your manuscript at www.biomedcentral.com/submit
C Biomed Central 